\title{
Effect of aluminium hydroxide on serum ionised calcium, immunoreactive parathyroid hormone, and aluminium in chronic renal failure
}

\author{
C K BISWAS, R S ARZE，J M RAMOS, M K WARD, J H DEWAR, D N S KERR, D H KENWARD
}

\begin{abstract}
According to the Bricker-Slatopolsky theory, secretion of parathyroid hormone (PTH) is switched on in chronic renal failure by hypocalcaemia due to phosphate retention. In an attempt to reverse this process 20 patients in preterminal renal failure (plasma creatinine $569 \pm$ $195 \mu \mathrm{mol} / \mathrm{l})$ were given aluminium hydroxide, $3.8 \mathrm{~g}$ daily. They were studied for four weeks and all measurements were made at the start and weekly, except measurements of serum aluminium concentration, which were made at the start and at the end of the fourth week. Mean serum phosphate fell from 1.89 to $1.47 \mathrm{mmol} / 1$ (5.9 to 4.6 $\mathrm{mg} / \mathbf{1 0 0}$ ), mean serum calcium rose from 2.07 to 2.24 mmol/1 (8.3 to $9.0 \mathrm{mg} / 100 \mathrm{ml})$, and serum ionised calcium rose from 1.07 to $1.20 \mathrm{mmol} / 1(4.3$ to $4.8 \mathrm{mg} / 100$ ml), but serum immunoreactive PTH did not fall. Thirteen patients had initial serum immunoreactive PTH concentrations at or near to normal and 11 were taking beta-blockers but even in those with neither explanation, PTH concentrations did not fall. Serum aluminium concentrations rose from 0.4 to $1.02 \mu \mathrm{mol} / 1$ (10.9 to $27.4 \mu \mathrm{g} / 1)$.

Aluminium hydroxide corrects serum phosphate, total calcium, and ionised calcium at the price of a rise in serum aluminium concentration; in this study it did not affect serum immunoreactive PTH. The BrickerSlatopolsky theory still needs verification in studies of patients with chronic renal failure.
\end{abstract}

\section{Introduction}

Secondary hyperparathyroidism is almost universal in chronic renal failure. All the evidence indicates that the secretion of parathyroid hormone (PTH) is regulated mainly by the concentration of serum calcium ${ }^{12}$; the best direct data are derived from studies in cows. ${ }^{3}$ Infusion of phosphate increases plasma immunoreactive PTH concentrations but only when the serum phosphate concentration is increased enough to cause a reciprocal depression of the serum calcium concentration.

In the light of these facts, hyperparathyroidism in chronic renal failure is generally thought to be caused by renal retention of phosphate via depression of the serum calcium concentration. The theory has been championed by Slatopolsky and Bricker, who have produced impressive evidence for it in dogs: administration of a very low phosphate diet, or progressive

Departments of Medicine and Clinical Biochemistry and Metabolic Medicine, Royal Victoria Infirmary, Newcastle upon Tyne

C K BISWAS, MB, MRCP, regional research registrar

R S ARZE, MD, research associate

J M RAMOS, MD, research associate

M K WARD, MB, MRCP, consultant physician

J H DEWAR, MRCS, PHD, principal biochemist

D N S KERR, MSC, FRCP, professor of medicine

Renal Unit, North Ormesby Hospital, Middlesbrough, Cleveland D H KENWARD, MRCP, consultant nephrologist reduction of dietary phosphate in proportion to the reduction in the glomerular filtration rate, prevented the development of secondary hyperparathyroidism, which was caused by a normal phosphate intake. ${ }^{4-6}$ This is a difficult experiment to reproduce in man because of the heterogeneity of chronic renal failure, the long time scale of its development, and the unpalatability of low phosphate diets. The few reported experiments have been limited to 60 days and have yet to be published in full."

The Bricker-Slatopolsky hypothesis could be confirmed indirectly by lowering plasma phosphate concentrations in patients who already have secondary hyperparathyroidism and watching the reversal of the process. Aluminium hydroxide is widely prescribed with this intention ${ }^{8}$ but we are unaware of any convincing proof that secondary hyperparathyroidism can be fully reversed as a result. This is partly because the aluminium is usually given with calcium carbonate or with one of the vitamin $\mathrm{D}$ analogues which simultaneously raise serum calcium values. A previous report from this centre showed that aluminium hydroxide alone depressed serum immunoreactive PTH in patients on regular haemodialysis, ${ }^{9}$ but this is an inadequate proof of the Bricker-Slatopolsky theory since haemodialysis raises serum calcium and depresses serum immunoreactive PTH concentrations. ${ }^{10}$

In an attempt to verify the hypothesis in man we gave aluminium hydroxide to patients in preterminal chronic renal failure with phosphate retention.

\section{Patients and methods}

Twenty patients with chronic renal failure (plasma creatinine 347-1009 $\mu \mathrm{mol} / 1(3.9-11.4 \mathrm{mg} / 100 \mathrm{ml})$, mean $569 \pm 195 \mu \mathrm{mol} / \mathrm{l}$ $(6.4 \pm 2 \cdot 2 \mathrm{mg} / 100 \mathrm{ml})$ were given aluminium hydroxide $3.8 \mathrm{~g}$ daily in divided doses (in the form of Alucaps) with meals over four weeks. Three had been taking $1.5 \mathrm{~g}$ calcium carbonate daily and one patient had been taking 1- $\alpha$-hydroxycholecalciferol $1 \mu \mathrm{g}$ daily for 14 months before the study, and these drugs were continued through the study period. No change was made in diet or drug treatment in the four weeks before the study or during it. None of the patients received cimetidine.

All measurements were made at the start of the study and weekly thereafter, except serum aluminium, which was measured at the start and at the end of the fourth week. The health of the patients was checked by clinical and laboratory investigations. Serum total calcium, phosphate, magnesium, protein, albumin, and alkaline phosphatase values were measured by standard Technicon SMA-plus autoanalyser techniques; serum ionised calcium concentrations were measured on the Orion SS20 ionised calcium analyser ${ }^{11}$ with the improved sensors introduced in 1978; serum aluminium was measured with a Perkin Elmer 603 atomic absorption spectrophotometer and an HGA 76B electrothermal atomiser; and serum immunoreactive PTH was measured by radioimmunoassay using Burroughs Wellcome antiserum 21/32 (MRC reagent 76/907). ${ }^{12}$

Student's paired $t$ test was used to compare the data at the start with those at each of the weekly intervals throughout the study.

\section{Results}

All patients were initially hyperphosphataemic (serum phosphate 1.58 to $2.85 \mathrm{mmol} / \mathrm{l}(4.9$ to $8.8 \mathrm{mg} / 100 \mathrm{ml})$. During the four weeks of aluminium hydroxide treatment mean serum phosphate fell from 1.89 to $1.47 \mathrm{mmol} / \mathrm{l}(5.9$ to $4.6 \mathrm{mg} / 100 \mathrm{ml})(\mathrm{p}<0.0025)$, ending just above 
the normal range for non-uraemic subjects (fig 1$)$. Serum calcium rose from 2.07 to $2.24 \mathrm{mmol} / 1(8.3$ to $9.0 \mathrm{mg} / 100 \mathrm{ml})(\mathrm{p}<0.005)$ and serum ionised calcium from 1.07 to $1.20 \mathrm{mmol} / 1(4.3$ to $4.8 \mathrm{mg} / 100 \mathrm{ml})$ $(p<0.005)$, both calcium fractions entering the normal range (fig 2$)$. Plasma bicarbonate concentrations fell slightly but significantly over the study period from 21.5 to $19.0 \mathrm{mmol}(\mathrm{mEq}) / 1(\mathrm{p}<0.05)$. Serum aluminium increased significantly from 0.4 to $1.02 \mu \mathrm{mol} / 1$ (10.9 to $27.4 \mu \mathrm{g} / \mathrm{l})(\mathrm{p}<0.005)$ but serum immunoreactive PTH was unchanged (mean before treatment $2 \cdot 16+1 \cdot 79 \mathrm{U} / \mathrm{l}$, after treatment $2 \cdot 20+1 \cdot 74$ $\mathrm{U} / \mathrm{l}$ ) (figs 3 and 4). Serum magnesium, total protein, albumin, alkaline phosphatase, and plasma creatinine values did not change significantly.

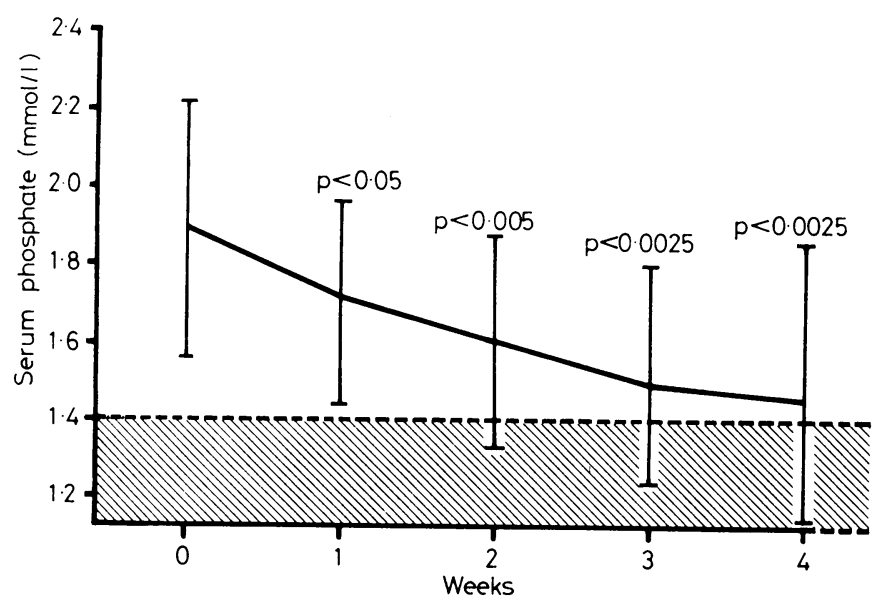

FIG 1 - Mean ( $1 S D)$ values showing effect of aluminium hydroxide on serum phosphate in 20 patients. Shaded area represents normal range. p Values show significance of difference from time 0.

Conversion: SI to traditional units-Phosphate: $1 \mathrm{mmol} / 1 \approx 3 \cdot 1 \mathrm{mg} / 100 \mathrm{ml}$.

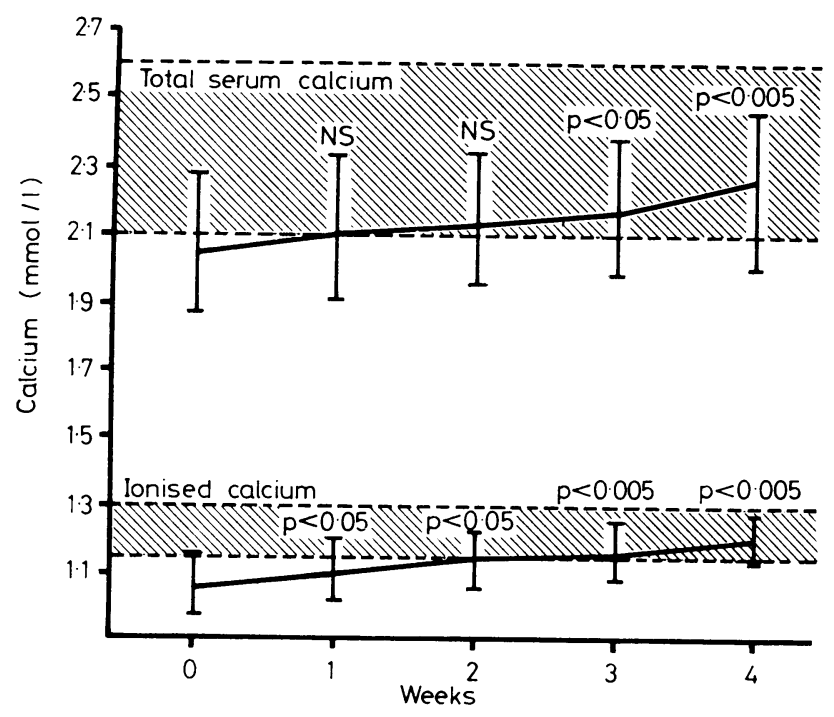

FIG 2-Mean ( 1 SD) values showing effect of aluminium hydroxide on total calcium and ionised calcium in 20 patients. Shaded area represents normal range. $p$ Values show significance of difference from time 0 . $\mathrm{ml}$.

\section{Discussion}

Our results confirm the Bricker-Slatopolsky theory inasmuch as lowering plasma phosphate resulted in a reciprocal rise in serum calcium and ionised calcium. The slight fall in plasma bicarbonate was unexpected and is not readily explained. One would not expect administration of aluminium hydroxide to increase acidosis, and the stability of plasma creatinine concen- trations in these patients over the four-week study make it unlikely that the decline was due to deteriorating renal function.

The surprising finding in the light of the Bricker-Slatopolsky theory was the stability of PTH in the face of significant changes in serum ionised and total calcium concentrations. We examined several possible explanations. Eleven of our patients were taking beta-blockers, which interfere with PTH secretion. ${ }^{13} 14$ Ideally studies of this sort should be carried out in patients taking no drugs, but most of those suffering from chronic renal failure have substantial hypertension and we did not feel justified in

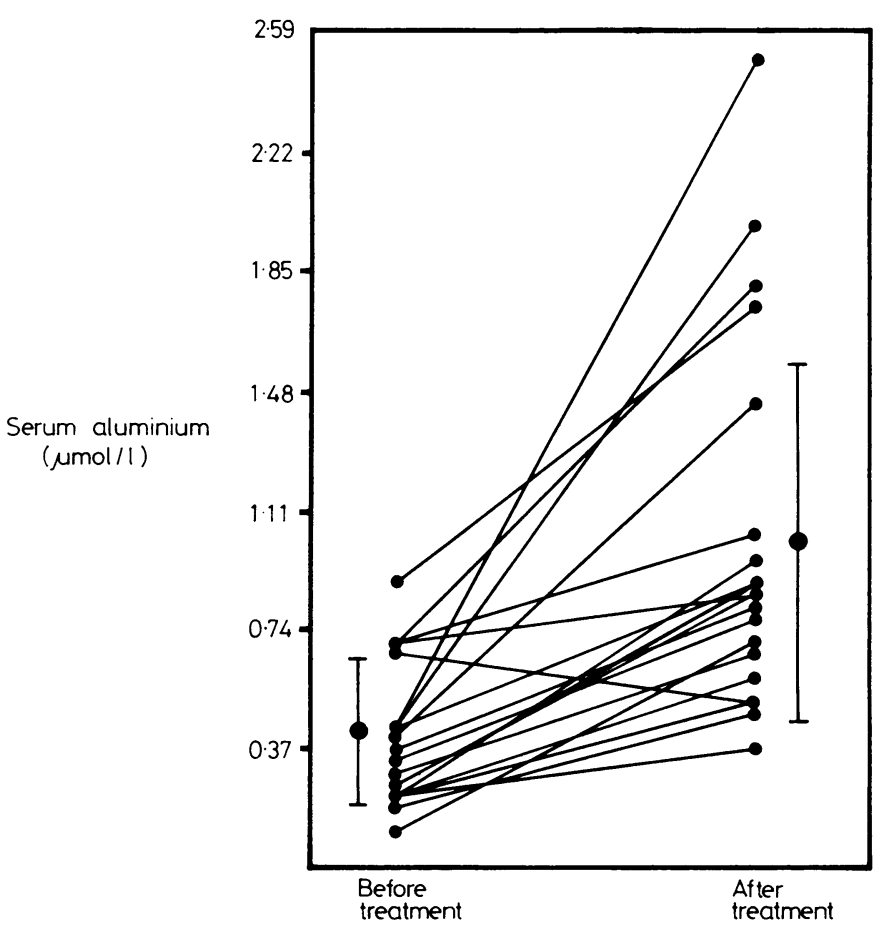

FIG 3-Serum aluminium concentrations in 20 patients with chronic renal failure before and after treatment. Means $( \pm 1 S D)$ are also shown (significance of difference: $p<0.005$ ).

Conversion: SI to traditional units-Aluminium: $1 \mu \mathrm{mol} / 1 \approx 30 \mu \mathrm{g} / 1$.

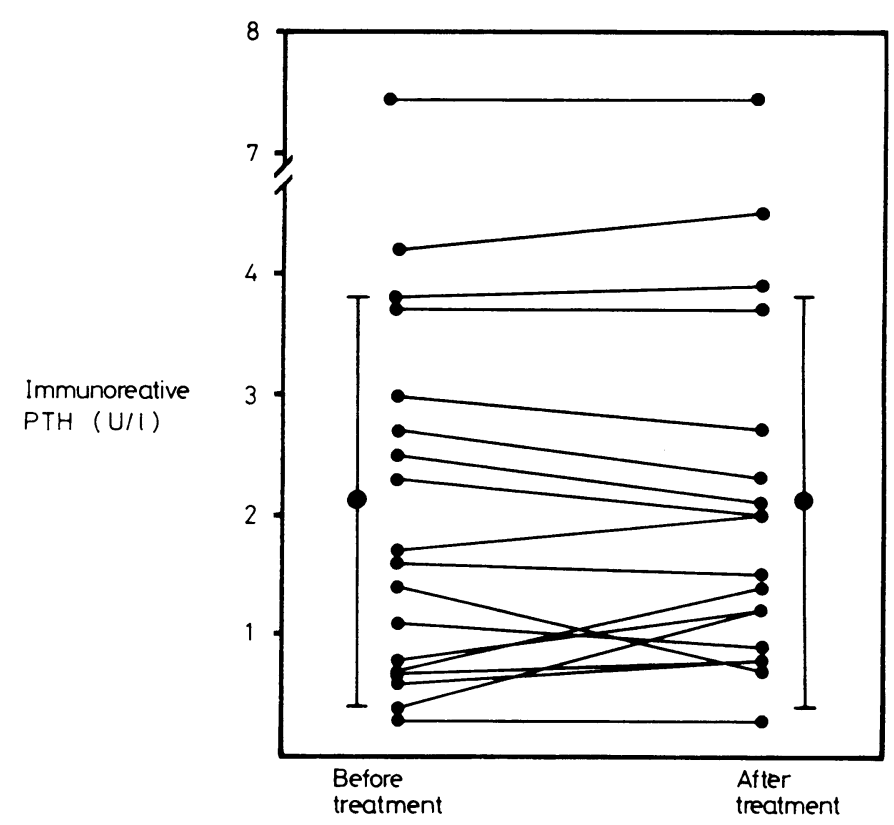

FIg 4-Serum immunoreactive PTH concentrations (U/1) in 17 patients with chronic renal failure before and after treatment. Means $( \pm 1 S D)$ are also shown. 
withdrawing antihypertensive drugs from well-stabilised patients for as long as four weeks. Some of the patients had PTH concentrations which were already close to normal and therefore could not have been expected to fall very far (fig 4). Even in the patients with initially high serum immunoreactive PTH concentrations who were not taking beta-blockers, however, there was no fall in these serum concentrations during aluminium hydroxide treatment. The PTH assay we used was not $\mathrm{N}$-terminal specific but it was capable of detecting changes in PTH secretion within a few hours when the serum ionised calcium was raised in renal failure by calcium infusion. ${ }^{9}$ The characteristics of the PTH assay were therefore unlikely to have been responsible for our failure to detect changes over four weeks. Factors other than phosphate retention, such as impaired secretion of 1,25-dihydroxycholecalciferol, may become important in maintaining the secondary hyperparathyroidism of preterminal renal failure, as Slatopolsky and his colleagues have suggested ${ }^{15}$; but our study showed that serum calcium concentrations can still rise into the normal range in preterminal renal failure if plasma phosphate concentrations are lowered, despite presumptive lack of active vitamin $\mathrm{D}$ metabolites.

The most likely explanation is that the parathyroid gland, once hypertrophied in chronic renal failure, ceases to respond to normal concentrations of serum calcium, though it can still be "switched off" by supranormal levels. ${ }^{16} 17$ If this explanation is correct, the reversal of hyperparathyroidism by lowering plasma phosphate may require a longer study period than we used. A longer study, concentrating on patients who have a high initial plasma immunoreactive PTH concentration, should now be undertaken but will not be easy since it is difficult to keep all other aspects of treatment constant over prolonged periods in late chronic renal failure. Until such a definitive study of the reversal of hyperparathyroidism has been performed, or more information on its prevention in early renal failure is available, the Bricker-Slatopolsky theory should be regarded as lacking proof in man.

We have confirmed observations that even a short period of administration of aluminium hydroxide in renal failure substantially raises serum aluminium concentrations. ${ }^{18-20}$ Aluminium intoxication causes dialysis encephalopathy and probably dialysis osteomalacia, anaemia, and general ill health. So far, nearly all described cases of these complications have been traced to aluminium absorption from dialysis fluid and it remains uncertain whether the modest aluminium absorption from drug treatment is a serious hazard. Until this question is answered it would be sensible to monitor serum aluminium concentrations in patients who receive aluminium hydroxide for long periods.

\section{References}

${ }^{1}$ Patt HM, Luckhardt AB. Relationship of a low blood calcium to parathyroid secretion. Endocrinology $1942 ; 31: 384-92$.

2 Dale DC, Sanford IR, Garcia GE. Effect of calcium on parathyroid secretion. Endocrinology $1965 ; 77 \cdot 725-30$

${ }^{3}$ Sherwood LM, Mayer GP, Romberg CF, Kronfeld DS, Aurbach GD, Potts JT. Regulation of parathyroid hormone secretion, proportional control by calcium, lack of effect of phosphate. Endocrinology $1968 ; 83$ : 1043-51.

+ Slatopolsky E, Caglar S, Pennell JP, et al. On the pathogenesis of hyperparathyroidism in chronic experimental renal insufficiency in the dog. f Clin Invest $1971 ; 50: 492-99$.

5 Slatopolsky E, Caglar S, Gradowska L, Cantebury J, Reiss E, Bricker NS. On the prevention of secondary hyperparathyroidism in experimental chronic renal disease using "Proportional Reduction" of dietary phosphorus intake. Kidney Int 1972;2:147-51.

${ }^{6}$ Rutherford WE, Bordier P, Marie P, et al. Phosphate control and 25hydroxycholecalciferol administration in preventing experimental renal osteodystrophy in the dog. $\mathcal{F}$ Clin Invest $1977 ; 60: 332-41$.

${ }^{7}$ Massry SG. Secondary hyperparathyroidism of renal failure. Evidence for a multifactorial pathogenesis. In: Zurukzoglu W, Papamiditriou $\mathbf{M}$, Pyrpasopoulus M, Sion M, Zamboulis C, eds. Proceedings of the 8 th International Congress in Nephrology. Basel: Karger, 1981:245-51.

${ }^{8}$ Lindholm T. Oral aluminium hydroxide in the treatment of hyperphosphataemia and acidosis in acute and chronic renal insufficiency. Acta Med Scand 1962;172:75-8.

' Hill AV, Thein-Than, Cook DB, Kerr DNS, Latner AL. The effect of lowering the serum phosphate on parathyroid hormone secretion and total serum calcium during regular hemodialysis. Clin Nephrol 1973;1 : 284-9.

${ }^{10}$ Conceicao S, Hoenich NA, Ward MK, et al. Ionised calcium during haemodialysis. Proc Eur Dial Transplant Assoc 1977;14:229-35.

11 Conceicao SC, Ward MK, Alvarez-Ude F, Aljama P, Smith P, Kerr DNS. Determination of serum ionised calcium by ion-exchange electrode in normal subjects. Clin Chim Acta 1978;86:143-51.

12 Brodie MJ, Boobis AR, Dollery CT, et al. Rifampicin and Vitamin D metabolism. Clin Pharmacol Ther 1980;27:810-14.

${ }^{13}$ Coevoet B, Desplan C, Sebert JL, et al. Acute effects of propranolol and metoprolol on plasma concentrations of parathyroid hormone and calcitonin in uraemic patients. Proc Eur Dial Transplant Assoc 1979;16: 649-55.

14 Brancaccio D, Galmozzi C, Casati S, et al. Propranolol and uraemic osteodystrophy. Proc Eur Dial Transplant Assoc 1979;16:668-71.

15 Slatopolsky E, Rutherford E, Hruska K, Martin K, Klahr S. How important is phosphate in the pathogenesis of renal osteodystrophy. Arch Intern Med 1978;138:848-52.

${ }^{16}$ Isaac R, Nivez MP, Piamba G, Fillastre JP, Ardaillou R. Influence of calcium infusion on calcitonin and parathyroid hormone concentrations in normal and haemodialysed subject. Clin Nephrol 1975;1:14-17.

17 Nielsen HE, Rømer FK, Melsen F, Christensen MS, Hansen HE. $1 \alpha$ Hydroxy Vitamin $\mathrm{D}_{3}$ treatment of non-dialysed patients with chronic renal failure, effects on bone, mineral metabolism and kidney function. Clin Nephrol 1980;13:103-8.

${ }^{18}$ Alfrey AC, LeGendre GR, Kaehny WD. The dialysis encephalopathy syndrome: Possible aluminium intoxication. $N$ Engl 7 Med 1976;294: 184-8.

19 Marsden SNE, Parkinson IS, Ward MK, Ellis HA, Kerr DNS. Evidence for aluminium accumulation in renal failure. Proc Eur Dial Transplant Assoc 1979;16:588-93.

20 Boukari M, Rottembourg J, Jaudon MC, Clavel JP, LeGrain M, Galli A. Influence de la Prise Prolongee de Gels d'alumine sur les taux seriques d'aluminium chez les patients attents d'insuffisance renale chronique. Nouv Presse Med 1978; 7:85-8.

(Accepted 6 November 1981)

ONE HUNDRED YEARS AGO Mr Noble Smith is taking up for the National Health Society the subject of fashionable deformities and the hygienic defects of modern dress of ladies, to which that Society has done so much to direct attention. A very healthy public feeling has been developed on this subject; and it is satisfactory to find that, on this occasion, a large audience assembled at Hampstead, under the presidency of $\mathrm{Mr}$ Spencer Wells, to hear what $\mathrm{Mr}$ Noble Smith had to say on the subject. The lecture was excellently illustrated by drawings, diagrams, and models; and $\mathrm{Mr}$ Noble Smith laid down the proportions of the human figure according to the rules of proportion of Professor Marshall, viz, that the average height of English women was sixty-three inches, the width across the chest nearly nine and a half inches; at the waist, the width should be nine inches, or but half an inch less than under the arms; and on the hips about eleven and a quarter inches, while the circumference of the waist should be a little over twenty-five inches. Respiration and circulation were impeded by tight lacing, which also produced palpitation of the heart, torpidity of the liver, indigestion, and degeneration of the muscles covered by the corset. The lecturer pointed out that the chief purpose of clothing should be to maintain an uniform temperature for part of the body. He also condemned the use of high-heeled tight, or short boots, and contended that, in clothing generally, easy locomotion and the free movement of the limbs should be provided for. He commended a "divided hygienic skirt" costume, made under the auspices of the Society, and exhibited, the peculiarity of which appeared to be general ease, with an under skirt resembling men's nether garments, loosely made, and giving freedom in walking and other movements. He advised ladies also to take more exercise than was their usual habit. The absurd notion that the human figure can be improved by artificial devices of compression and distortion, to suit the varying fancy of the modish dressmaker, is an idea which all sensible persons treat with mingled ridicule and amusement, but which still exists as an accepted dogma in the minds of ordinary Englishwomen; and if the National Health Society can succeed in fanning to a flame the present sparks of reason which are showing themselves with some promising brightness, and inducing Englishwomen to adopt rational principles as the guide to dress and personal decoration, in lieu of arbitrary follies, it will have rendered an acceptable service. For this purpose, however, as for any other social reform of the kind, much perseverance and continuous hammering will be needed. (British Medical fournal, 1882.) 